\title{
種々の下部組織を持つ工業用純アルミニウム 溶接熱影響部の再結晶挙動*
}

\author{
益本功**, 平阮仁**

\section{Recrystallization Behaviour of Heat Affected Zone of Commercial Pure Aluminium with Various Substructiures*}

\author{
by Isao Masumoto** and Hirohito Hira**
}

\begin{abstract}
Recrystallization behaviour of commercial pure aluminium may be affected by the morphology of substructures.

In this study, commercial pure $\mathrm{Al}$ of $10 \mathrm{~mm}$ thick plate was prepared. That was machined to the plates of various thickness, then these were full annealed at $600^{\circ} \mathrm{C}$ for $30 \mathrm{~min}$.

All plates were made equal to $2 \mathrm{~mm}$ thick plates by three kind of treatments, these were cold-rolling, cold-rolling and $200^{\circ} \mathrm{G} \times 30 \mathrm{~min}$. annealing (in this report, quasi stabilized treatment=Q.S.T.) and hotrolling. Each treatment induced another type of substructure, i.e. tangled dislocations, statically recovered structure, and dynamically recovered structure.

Recrystallization behaviour of these three types of substructure-induced specimens was studied by isothermai heat treatments at various temperatures.

And, softened width and recrystallized grain diameter at the electron beam weld heat affected zone of substructure-induced plates were compared. Test plates were $100 \mathrm{~mm} \times 100 \mathrm{~mm}$ square plates of $2 \mathrm{~mm}$ thickness.

Obtained results were as follows;

(1) Annealing at $200^{\circ} \mathrm{C}$ for $30 \mathrm{~min}$. after cold-rolling gave smaller recrystallized grain diameter and higher recrystallization temperature than cold-rolled test specimens.

(2) The higher the hot-rolling temperature, the higher the recrystallization temperature became, but slight change of recrystallized grain diameter was observed.

(3) While hardness of substructure-induced test specimen was below 30, hot-rolled test specimens had higher recrystallization temperature and smaller grain diameter than cold-rolled with or without Q.S.T. specimens.

(4) Softened width and grain diameter of electron beam weld heat affected zone of cold-rolled plates were larger than these of cold-rolled with Q.S.T. or hot-rolled plates.
\end{abstract}

\section{1. 緒 言}

溶接における熱影響部，特にボンド部の再結晶粒粗大 化は継手の機械的性質に影響を与え，一般には劣化する したがってての問題は溶接における重要な課題であり， いくつかの研究例がある.例えば工業用純アルミニウム の冷間加工材について, 井川等 ${ }^{12}$ は再結晶式を提案し, その式から溶接熱サイクルが与えられた場合の再結晶軟 化籍四を求めている.しがし Kašpar 等2)は，純アルミ

\footnotetext{
*原稿受付 昭和54年10月 2 日（昭和54年度泰季全国大会にて発表）

**正貝 名古屋大学工学部 Member, Faculty of Engineering, Nagoya University

***学生 員 名古屋大学大学院 (現在川崎重工業(株)技街研笕所) Student Member, Graduate School of Nagoya University (Present Address; Kawasaki Heavy Industries Ltd. )
}

ニウムの積層欠宿エネルギーが高いため，加工によって 導入された転位は再配列し安定な転位構造を形成しやす く，それが起てった場合は再結晶が起こりにくいことを 報告している。また難波 3 等は，熱処理状態によって， 冷間加工した工業用純アルミニウムの溶接熱影薌部再結 晶挙動が変化するてとを報告しているが, この結果は, 熱処理によって転位分布が変化しそれが再結晶に影響を 及ぽしたすのと推察される。

このように母材の下部組織状態が，溶接熱影響部の再 結晶挙動にも影響を及ほしているてとが考えられるの で，本研究は，それをより明らかにするため工業用純了 ルミニウム1200を用いて実験を行ったあのである．すな わち冷間生延，冷間压延後雨結晶温度以下での焼なま し，そして熱間圧延によって種々の状態を有する下部組 
織を得た。そしててれらについて各種の条件の焼なまし を行い, 再結晶温度及び再結晶粒径への初期下部組織状 態の影響を調べた.さらにとれらの結果と, $2 \mathrm{~mm}$ 厚の 試験板を電子ビーム溶接したさいの熱影響部の再結晶挙 動とを比較検討した。

そして, 溶接熱サイクルに対して, 再結晶軟化域の拡 がりを防ぎ，再結晶粒を小さくするような下部組織を明 らかにした。

\section{2. 実 験 方 法}

\section{1 下部組織の導入}

供試材としては Table 1 亿示す化学成分の工業用純 アルミニウム1200を用いた．板厚は $10 \mathrm{~mm}$ であったが 切削するととによって種々の板厚に変化させた，それら は，まず $600^{\circ} \mathrm{C} \times 30$ 分の焼なましを行い，結晶粒径を約 $100 \mu \mathrm{m}$ とした。 そして次に示すような下部組織を得る 種々の処理を行った。

Table 1 Chemical composition of pure $\mathrm{Al}$ used.

\begin{tabular}{c|c|c|c|c|c|c|c|c}
\hline \hline $\mathrm{Cu}$ & $\mathrm{Si}$ & $\mathrm{Fe}$ & $\mathrm{Mg}$ & $\mathrm{Mn}$ & $\mathrm{Zn}$ & $\mathrm{Cr}$ & $\mathrm{Ti}$ & $\mathrm{Al}$ \\
\hline 0.04 & 0.14 & 0.33 & 0.01 & 0.03 & 0.03 & 0.01 & 0.01 & bal. \\
\hline
\end{tabular}

圧延率 $80 \%$ までの泠間圧延を行い, 転位の七ル構造を 得た。 そしててれらの冷間圧延材を 200 Cで 30 分焼なま し転位の再配列を促進させた．この $200^{\circ} \mathrm{C} \times 30$ 分の焼な まし処理は，転位の再配列による転位構造の準安定化を はかったあのであるので, 今後は単に準安定化処理 （quas'stabilized treatment $=$ Q. S. T) と呼ぶこととす る.

また熱間圧延後急冷するととによって，高温加工で動 的に形成される組織を得た。圧延は予め $600^{\circ} \mathrm{C}, 500^{\circ} \mathrm{C}$, $350^{\circ} \mathrm{C}$ の炉に加熱した試験材を用い 1 パスで $60 \%$ の圧延 を行い直ちに水冷した. ただし压延温度としては, 水温 の上昇加計算して求めた值を実験結果の整理に用い た. なおすべての試験片は, 以上の処理中に压延率を適 当に定めるととにより, 処理後はすべて $2 \mathrm{~mm}$ 厚に統一 された。

Fig. 1 亿透過電子顕微鏡による下部組織の観察例を示 す. (A) の60\%冷間圧延のままのあのでは加工によっ て導入された転位が集合体となってセル構造を作ってい るのが観察される. (B) は (A) を準安定化処理したもので (A) より転位の再配列が促進され静的な回復が進行して いる. (C) は $180^{\circ} \mathrm{C}$ 熱間圧延による組織であるが，小さな 亜結晶が観察され動的回復が起こっていると考えられ る4). (D) $9450^{\circ} \mathrm{C}$ 熱間圧延の組織では亜結晶粒径がかな り大きくなり, 粒間のコントラストにみられるように傾

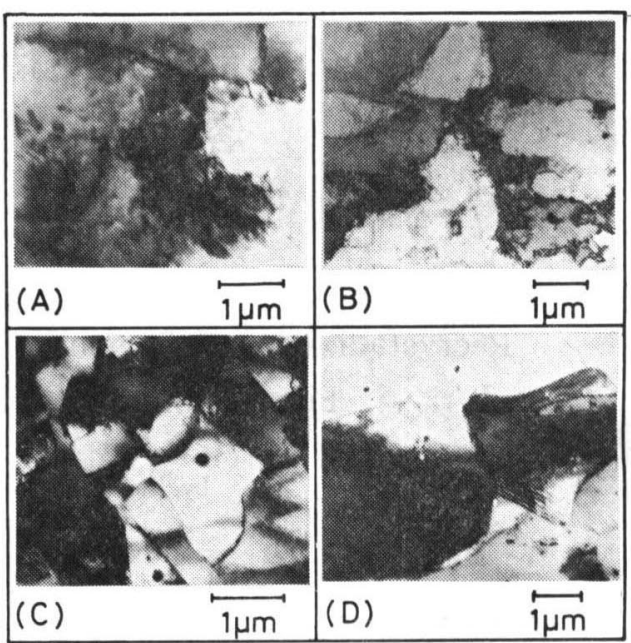

(A) $60 \%$ cold-rolled

(B) $60 \%$ cold-rolled and annealed at $200^{\circ} \mathrm{C}$

(C) $60 \%$ hot-rolled at $180^{\circ} \mathrm{C}$

(D) $60 \%$ hot-rolled at $450^{\circ} \mathrm{C}$

Fig. 1 Transmission electron micrographs of substructures of $\mathrm{Al}$ by various treatment.

觔が大くなってくる.

Fig. 2 (a) は横軸の各圧延率で泠間圧延, 及び冷間圧 延後準安定化処理を行った試験材の硬さ, Fig. 2 (b) は横 軸の各温度で $60 \%$ 熱間圧延を行った場合の硬さの変化を 示す. Fig. 2 (a) より圧延率の増加に伴い硬さが上昇する が, 準安定化処理によってはそ机ぼ゙硬さが低下しない ととがわかる.また Fig. 2 (b) によって圧延温度が2000 以上になると硬さが急激に低下することがわかる.

\section{2 再結晶挙動の観察}

2.1 のように下部組織を導入した試験材を, 塩浴に保 持した後水中に急冷した. そのさいの保持温度及び保持 時間を種々変化させた．そして試験材の硬さと光学顕微 鏡組織の変化から再結晶温度, 再結晶粒径を調べた。

また $2 \mathrm{~mm}$ 厚の各試験材から $100 \mathrm{~mm} \times 100 \mathrm{~mm}$ の板 を切りだし，その中央部に電子ビームによって圧延方向 に直角に長さ $50 \mathrm{~mm}$ のビード溶接を行い, 溶接熱影響 部の再結晶挙動の観察を行った. そのさい電子ビーム溶 接条件は, 溶融線が表側から裏侧まで Fig. 3 のように平 行となるような Table 2 の条件を選んだ.

\section{3. 実験結果及び考察}

\section{1 定温保持による再結晶挙動}

Fig. 4 は圧延率 $80 \%$ 及び10\%の冷間圧延のままの試験 材, 及びそれらに準安定化処理を行った試験材を, 横軸 


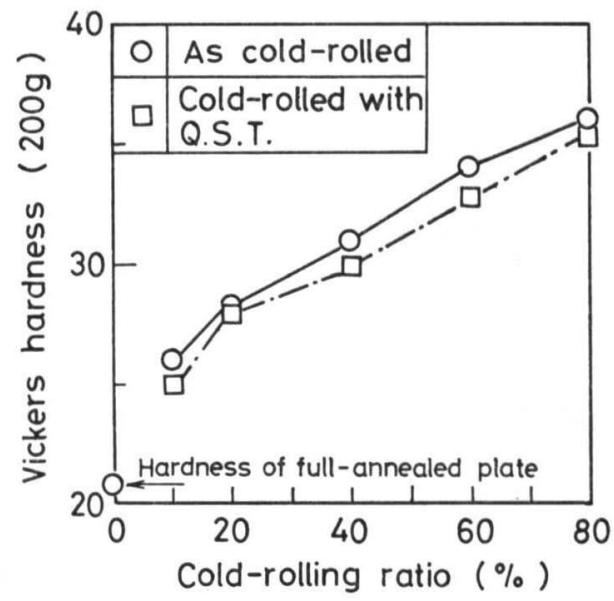

Fig. 2 (a) Effect of cold-rolling ratio and quasi stabilized treatment on hardness of test specimens.

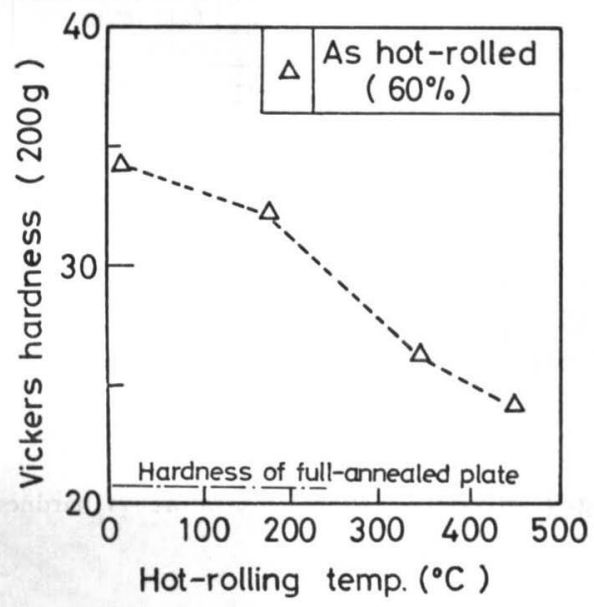

Fig. 2 (b) Effect of hot-rolling temperature on hardness of test specimens.

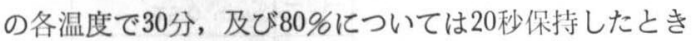
の硬さむ示す.

冷間圧延のままのあのの30分保持の結果では, 圧延率 $80 \%$ ののの硬さは10\%のあのに比べ当然のととながら はるかに高いが, 前者は約 $250^{\circ} \mathrm{C}$ で硬さは急激に低下し 300 C でほぼ完全に軟化しているのに対し, 後者では $300^{\circ} \mathrm{C}$ までの硬さの低下はわずかで $400{ }^{\circ} \mathrm{C}$ で完全に軟化し ている。準安定化処理したものは冷間压延のままのむの と此へ，特に圧延率10\%の場合, 保持時間 30 分でも, 軟 化の開始温度がやや高く, 再結晶温度が上昇しているこ とがわかる. しかし，圧延率80\%のあのは，保持時間 30 分ではそれらの軟化開始温度に差はあらわれないが, 保 持時間 20 秒と短い場合には, 雨者とも $3500^{\circ} \mathrm{C}$ 以上に軟化 開始温度が上昇し，そして準安定化処理材の方が上昇度

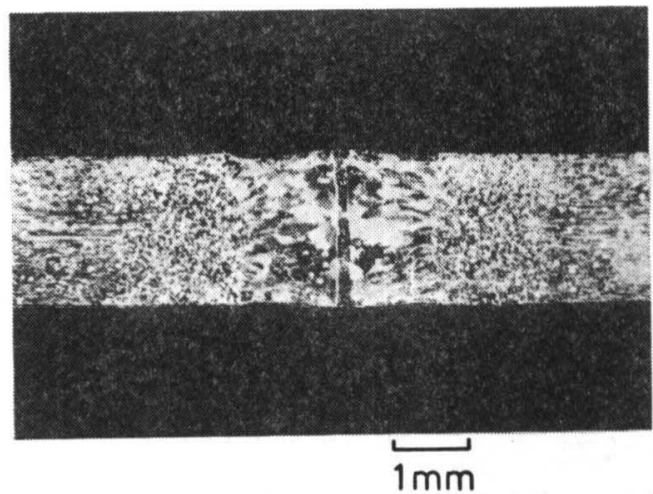

Fig. 3 Macrosection of E.B. weld.

Table 2 E.B. welding condition.

\begin{tabular}{l}
\hline E. B. welding condition \\
\hline Accelerating voltage $: 150 \mathrm{kV}$ \\
Beam current $: 40 \mathrm{~mA}$ \\
Welding speed $: 1500 \mathrm{~mm} / \mathrm{min}$ \\
Focal distance $: 170 \mathrm{~mm}$ \\
Objective distance $: 240 \mathrm{~mm}$
\end{tabular}

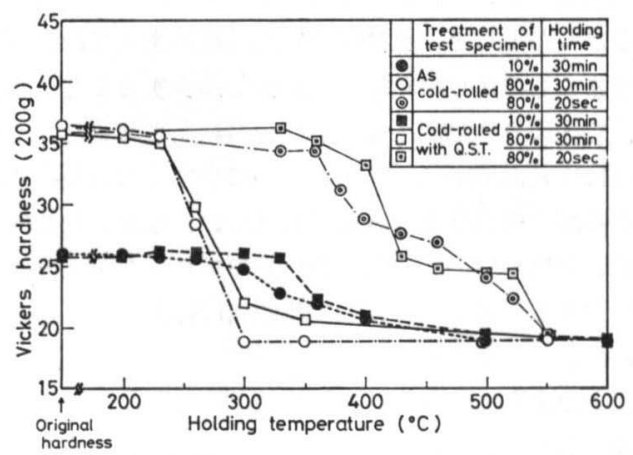

Fig. 4 Effect of holding temperature and time on softening of cold-rolled test specimens with and without quasi stabilized treatment.

が大きい。

Fig. 5 は60\%熱間圧延材及び $60 \%$ 冷間圧延材を横軸の 各温度で 30 分もしくは20秒保持したときの硬さを比較し たものである. 30 分保持の結果より，60\%冷間圧延材は Fig. 4 の $80 \%$ 冷間压延材の場合と同様に $250^{\circ} \mathrm{C}$ で硬さ が低下し $300{ }^{\circ} \mathrm{C} て ゙$ 完全に軟化している. 熱間圧延材につ いてみれば圧延温度が低いほど元の硬さは大きいが, 軟 化開始温度は逆に低下している。 なお保持時間が20秒と 短い場合には, 压延温度 $180^{\circ} \mathrm{C}$ ののは $400^{\circ} \mathrm{C}$ 近くから硬

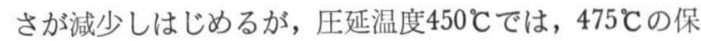
持温度でようやく硬さの低下がみられる，しかしどちら あ完全に軟化するのは 500 C 以上である.

次にこれらの下部組織を導入した試験材を, それらが 


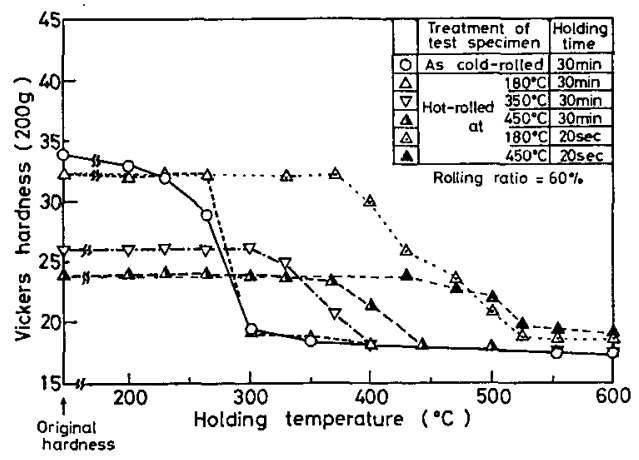

Fig. 5 Effect of holding temperature and time on softening of cold-rolled and hot-rolled test specimens.

完全に軟化する $500^{\circ} \mathrm{C}$ 以上の温度で20秒，及び 30 分 保持 し，再結晶させてその粒径を测定した。そして特に， Fig. 3 で示される電子ビーム溶接熱影嵬部の再結晶粒径 に近い $550^{\circ} \mathrm{C} \times 20$ 秒の結果で比較するとととした. Fig. 6 はその結果で, 左図が冷間圧延のまま, 及びそれて準 安定化処理を行ったあのの結果，右図が熱間圧延のもの の結果を示す．左図より圧延率の增加化伴い再結晶粒径 が小さくなるとと，及び準安定化処理によって冷闒圧延 のままのものより再結晶粒径が少し減少するととがわか る。右図より，熱閏压延のあのを再結晶させると，その 粒径は压延温度が高温側でわずかに小さくなる傾问がみ られるが，それほど大きな変化はない，なお，他の保持 温度，保持時間の結果は，Fig. 6 のプロットが上方に平 行移動する程度で模軸に対する傾向にはあまり变化はな

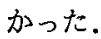

以上のように，3程類の処理によって異なる下部組織 を導入した試験材は，各々特有の再結晶挙動をすること が観察された。下部組織を導入するととは同洔に機械的 性質をあ変化させるとととなり，もっとも簡単な例とし ては，Fig. 2亿みられるように，硬さが各々の加工及び熱 処理によって上昇している，そてで，との硬さというあ のを機械的性質の目安とし，各処理を行ったときの試験 材の硬さとその再結晶挙動との関係を調べることとした.

Fig. 7 は再結晶温度之各処理を行ったときの詿験材の 硬さとの関係, Fig. 8 は再結晶粒径之試験材の硬さとの 関係を示す.な扔再結晶温度は，Fig.4，Fig. 5 でみられ るように各温度で30分保持したさい，保持後の試験材の 硬さが，各処理を行ったままの硬さと完全化軟化しきっ たときの硬さとの中間の硬さとなる温度とし，その温度 付近では集中的に追加実験を行った，また，再結晶温度 については, Fig. 6 の結果を利用した.

Fig. 7 より，各処理を行ったままの下部組織が導入さ れている試験材の硬さと, 再結晶温度とは全体にほほ直

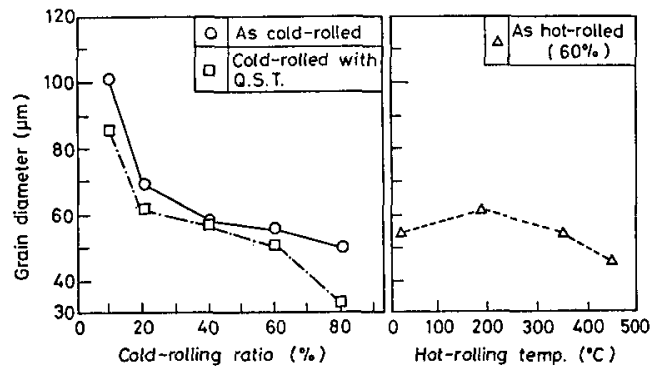

Fig. 6 Effect of cold-rolling ratio or hot-rolling temperature on recrystallized grain diameter of test specimens after $550^{\circ} \mathrm{C} \times 20 \mathrm{sec}$. annealed.

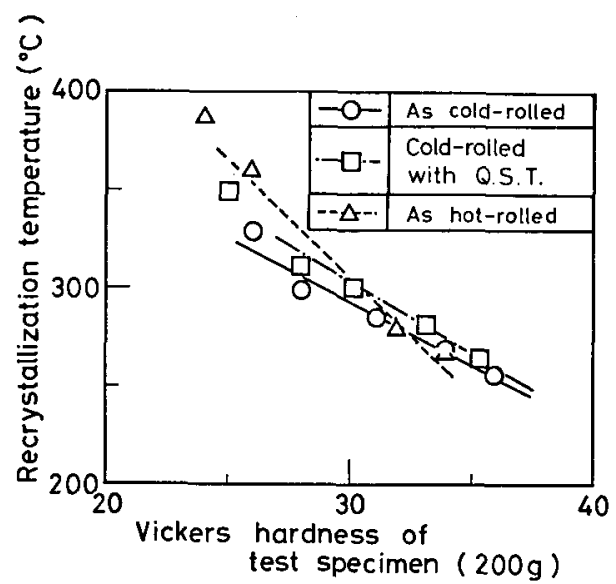

Fig. 7 Recrystallization temperature vs hardness of base metal.

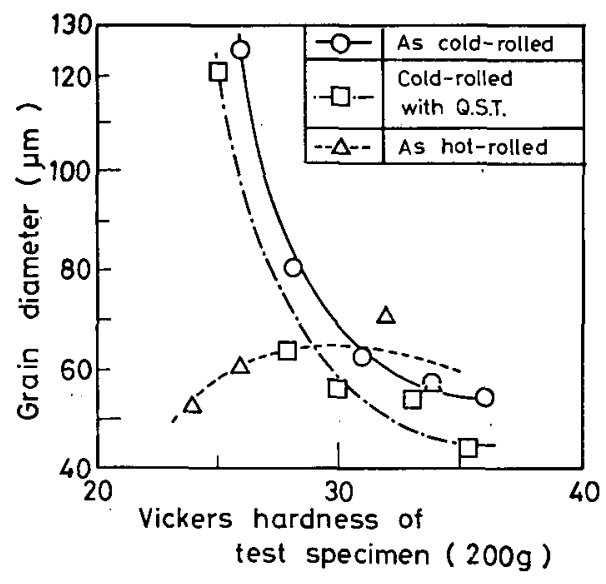

Fig. 8 Recrystallized grain diameter vs hardness of base metal. 
線関係にあり, 硬さが小さなほど再結晶温度が高い，そ して硬さが大きな範囲では 3 種類の処理材間にはそれほ どの差はないが, 硬さが30以下の笓囲では, 冷間圧延の 屯のは再結晶温度が少し低めの傾向があり, また熱間圧 延のあのは高めの傾向を持っており, 準安定化処理を行 ったあのはその中間の值を持っている.

Fig. 8 の各処理を行ったときの試験材の硬さと再結晶 粒径との関係では, 硬さの大きな領域では Fig. 7 の結果 と同様に 3 種の処理材間でそれほどの差はないが, 硬さ が30以下となるとほぽ同様の硬さであ粒径にかなりの差 がみられ, 冷間圧延のものが最も粗大化し, 熱間圧延の あのは逆に最む小さく, 準安定化処理を行ったものは, 冷間圧延材より小さめの結果を示す.

このように硬さが大きな範囲では 3 種の処理材ともほ ぼ同様の再結晶挙動を示すが, 硬さ30以下の範囲では, ほほ同一の硬さでも再結晶挙動が異なり, 冷間圧延のま まの屯の, 準安定化処理したあの, 熱間圧延の屯のの順 に, 再結晶温度が上昇し再結晶粒径が小さくなる原因は 次のように考えられる.

加工によって導入された下部組織は金属の内部エネル ギーを高めており，焼鈍など外から熱エネルギーを与え ると, それらの下部組織が消滅したり, 再配列するとと によって内部エネルギーを解放しようとする．それが完 全に消滅した状態が再結晶である. しかし, 純アルミニ ウムのような積層欠陥エネルギーの高い金属では, 加工 のさい導入された転位は再配列を起こしやすく，そして その再配列が起こると内部エネルギーをかなり解放する ととができるため再結晶が起とりにくくなる2).

以上の現象が，この実験では特に硬さ30以下のあので
顕著に現われ，冷間加工のままのセル構造より，ある程 度転位の再配列の進んだ準安定化処理を行った組織, ま たそれよりはっきりした亜結晶粒界を持った熱間圧延に よる組織の順に, 同じ硬さでも内部エネルギーが小さく そのため再結晶核生成及び成長が起とりにくくなったも のとおむわれる。

しかし硬さ30以上の範囲では，七ル構造とか亜結晶粒 界を形成させて少し内部エネルキ゚ーを低下させてむ，依 然, 全体としての再結晶へのドライビングホースは非常 に大きく, また再結晶の核生成場所屯, 硬さの小さなむ のに較へてて相当多いととが考えられるため， 3 種の処理 材とも, 差が顕著に現われないような短時間で再結晶が 終了してしまうあのとおあわれる，しかし，硬さの大き な範囲であ, 保持時間を短くし再結晶の初期過程をとら えるととによって各処理材間の差は得られやすくなる.

Fig. 4 の80\%冷間圧延材とその準安定化処理材の結果は その一例で，30分保持では両者の軟化開始温度に差はな いが，20秒保持では準安定化処理材の方が高温側になっ ており, 硬さの大きな範囲であ, 準安定化処理によって 内部エネルギーが低下しているあのを意味するのである.

\section{2 電子ビーム溶接熱影響部の再結晶挙動}

3.1 のように下部組織の存在状態によって再結晶挙動 が変化したが, このととは当然溶接熱影響部の再結晶挙 動にあ影響を与えるあのと考えられる．

Fig. 9 は電子ビーム溶接熱影響部の光学顕微鏡組織の いくつかの例で，母材は (A) が60\%冷間圧延のもの, (B) か360\%冷間圧延後 $200{ }^{\circ} \mathrm{C} \times 30$ 分の準安定化処理を行 った あの，(C) は $450^{\circ} \mathrm{C} て ゙ 60 \%$ の熱閒圧延を行ったものであ る. (A) と (B) の比較により, 準安定化処理を行った

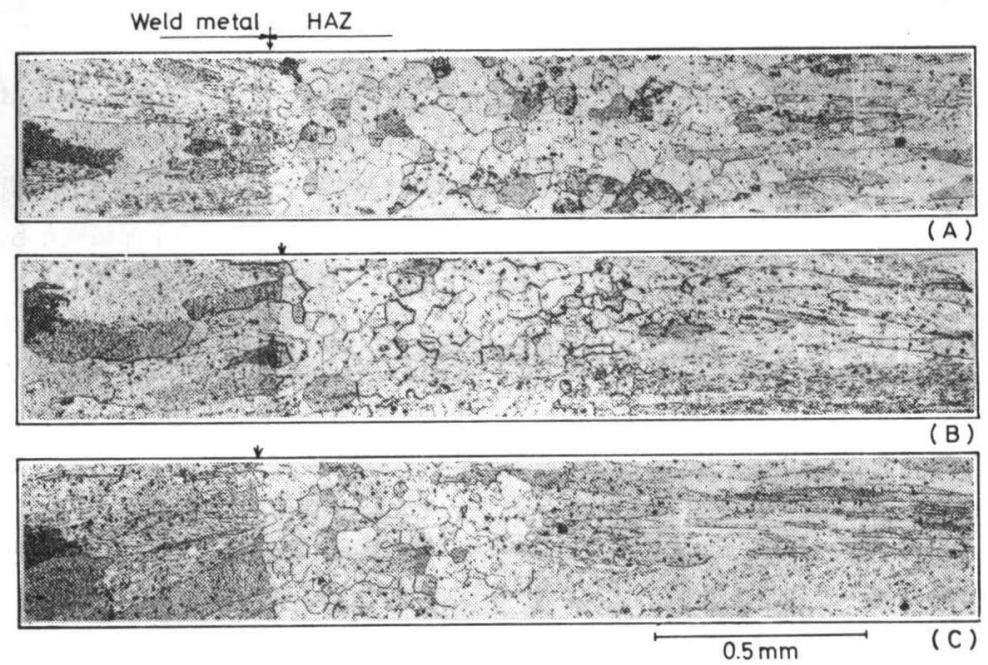

Fig. 9 Optidal micrographs of heat affected zone. (A) $60 \%$ cold-rolled (B) $60 \%$ cold-rolled and annealed at $200^{\circ} \mathrm{C}$ (C) $60 \%$ hot-rolled at $450^{\circ} \mathrm{C}$ 
(B)は，再結晶領域は(A)より狭くなっているが，融合線 付近の再結晶粒の径は $(A)$ とほ浔同㥞であるととが観察 される。また (A) 之 (C) の比較加ら (C) の熱問压延材の 方が再絊昆頒域むまた再結暃粒径む小さなととがわか る.

これらの熱影響部の笓䧃，及び再結昆粒径を各下部組 織を有する各試験板について調べた，Fig. 9 にみられる ように，ボンド部の結晶粒は，エピタキシアル凝固成長 の核として㗢くことから，乙の部分の結晶粒径が凝固金 属の性質偣影響を与えていると考えられる．そとで融合 線上の粒界間の平均距離を求め，その值をボンド部の再 結晶粒径とし, 各試験板について比較を行った。また再 結晶領域については, 硬さ測定によって软化域を調べ た.

Fig. 10 は,ボンド部の再結晶粒径と, 各処理を行って 下部組織を導入した試験板の溶接前の硬さとの関係を示 すものである．図より冷間庄延を行ったもの，及びそれ に準安定化処理を加えたものは，硬さの上昇とともに急 激に結晶粒が細䊀化しているが, 熱間圧延のものは硬さ の変化に伴なう結晶粒径の変化はほとんどみられず概し て細粒である，また準安定化処理したすのは，冷關圧延 のままのあのより少し粒径が小さい傾向がタられる，て の結果は，Fig. 8 の試験材を定温保持したときの再結晶 粒の絬果とほほ対応している。

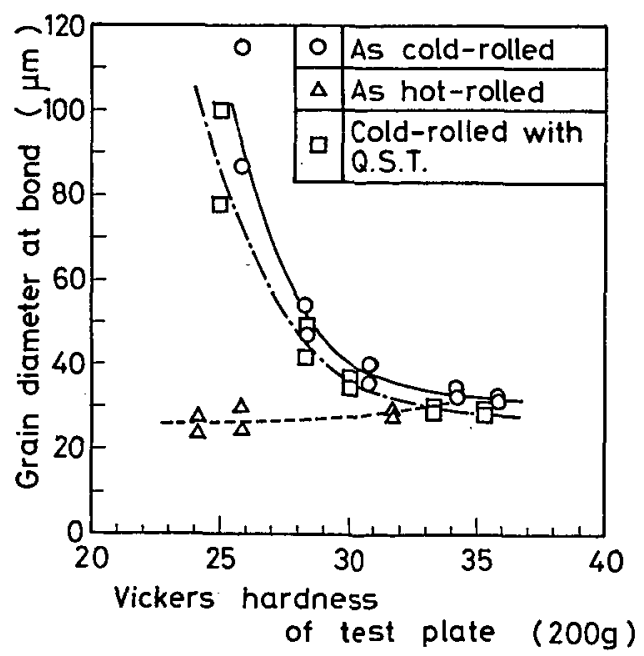

Fig. 10 Effect of induced microstructures on the recrystallized grain diameter of bond.

Fig.11は融合線から母材への熱影響部の硬さ分有を 示すものである，下側の図は60\%冷間圧延のまま，及び それを準安定化処理したものの結果である．準安定化処 理によってかなり軟化城が狭くなっている。このととは

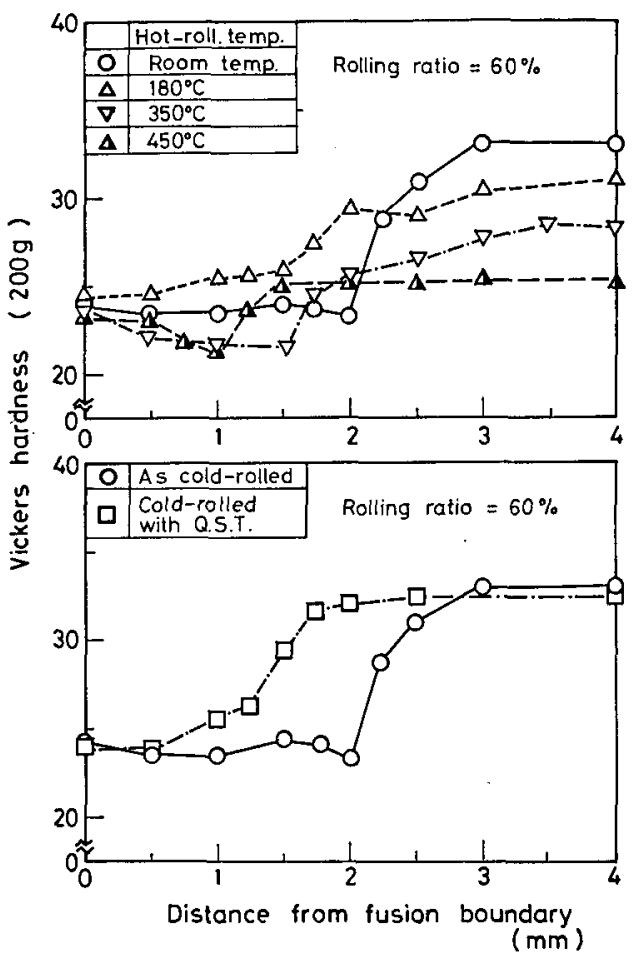

Fig. 11 Effect of base metal condition on the hardness distribution of heat affected zone.

軟化温度が高いととを意味しており、F:g. 4 の傾向と一 致する．上側の四は，図中の温度で熟間圧延したものの 結果である。熱間庄姃温度の上梨とともに硬さが低下 し，そして軟化域屯減少している。すなわち Fig. 5 K 示すごとく圧延温度が高いほど，試験板の硬さは低いが

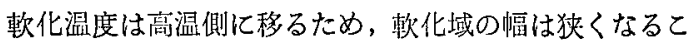
ととなる。

下部組織導入に伴う硬さの上昇量が，溶接熱サイクル によって1/2以下まで欶化する㑯域を，欶化城の幅として との值と溶接前の試験板の硬さとの関係を求めたのが Fig. 12 である. 3 種の下部組織とも武験板の硬さの低 下洋い，軟化域が狭くなっている，準安定化処理を 行ったあのはすへてて硬さ籁囲にわたって約 $1 \mathrm{~mm}$ 弱 赖化域が，冷間圧延のままのむのより狭い，蓺間圧延の あのはその中間位㯰しているが，硬さの大きな䇥团で は冷間圧延材，硬さの小さな筑四では準安定化処理を 行ったむのに近い.

もし試験板の再結昆温度が䓵いほど㳄化域の幅が狭く なるとするならば，Fig.12 は Fig.7 の再結晶温度の結 果之対応して，硬さの大きな側では烒験板の状態によら ず軟化域が広くなり，硬さの小さな㑡では备試験板と屯 軟化域は犷㹟くなが，熹間圧延材がもっとも狭く，そし 


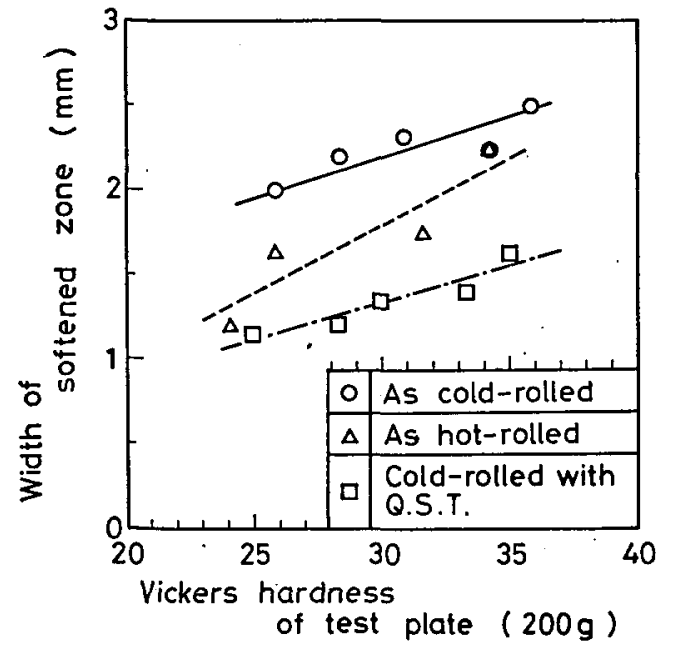

Fig. 12 Effect of induced microstructures on the width of softened zone.

て準安定化処理を行ったもの，そして冷間压延のままの まのあのの順に広くなると考えられる，し加し，冷間压 延のままの白の之熱閪圧延忉の比較に扔いては，それに よく対応する結果が得られたが，準安定化処理したもの は全硬さ範囲で軟化域が狭くなる傾向がみられた，この ことは $200^{\circ} \mathrm{C} \times 30$ 分 の準安定化処理によって転位が集合 する以外に，微量不純物が粒界に析出するなどの現象が 起こり, 短時間の溶接熱サイクルに対しては, 再結晶軟 化を抑制するようなととが起とるのかす知れない5).

純アルミニウムは政なまし状態だけではなく，冷間加 エなどによって強化された状態で用いられることがある が，それらに溶接が必要とされるとき，再結昆軟化領域 はできるだけ狭く，また粒径が粗大化しないことが望ま れる，この研究において，母材が同じ硬さであっても導 入されている下部組織状態によって再結昆挙動が買なる ことが明らかとなった。 Fig. 10 及び Fig. 12 の結果よ り, 強度の大きな母材が必要な場合には, 冷間加工後準 安定化処理を行ったすのを用いることにより, 溶接によ る軟化域を㹨くすることができる，また，強度がそれほ ど大きくなくともよい母材が必要とされる場合は，熱間 王延材を利用するととによって, 再結晶軟化範困が狭 く，しかすボンド部が粗粒化しないような継手を得るこ とができる.

\section{4. 結}

言

溶接熱影響部の再結晶挙動に及ぽす下部組織の影響を 明らかにするために，純アルミニウムに冷閶圧延，冷間
圧延後 $200{ }^{\circ} \mathrm{C}$ で 30 分の熱処理, 熱間压延の各処理を行い 3 種の異なる状態の下部組織を有する試験材を作成し， 各温度での定温保持による再結晶温度, 及び再結晶粒径 の変化を調べた.さらにてれらの試験材について電子 ビーム溶接を行い，それらの熱影響部を調べた。

得られた結果は以下の通りである.

1） $30 \%$ 以下の冷間圧延の場合, 再結晶粒の粗大化が 顕著であるが, $200^{\circ} \mathrm{C} \times 30$ 分の準安定化処理を行うとと により，その粗大化が抑制され，再結晶温度も上䊬する ことを確かめた。

2）加工度が60\%以上の玲間圧延では，準安定化処理 を行っても再結晶温度は上昇しなかったが，再結晶粗大 化の抑制には効果があった。

3）熱間圧延材の場合, 圧延温度の上昇に伴って再結 晶温度は上昇するが, 再結晶粒径はほとんど变化しな 加った。

4) 試験材を同一硬さで比較した場合, 熱間压延によ る試験材は, 冷間圧延のむのや準安定化処理したもの上 り再結晶温度は高く, 再結晶粒径は小さかった。

5）乙れらの試験材の電子ビーム溶接熱影響部の軟化 域の幅及び再結晶粒径を測定した。冷間区延材の熱影響 部は軟化域の幅が広く, 再結晶粒径が粗大化しがちであ るが，これに較へ， $200^{\circ} \mathrm{C} \times 30$ 分の準安定化処理した試 験材, 及び熱間压延材では, 乾化域が狭く, 再結晶粒径 あ小さいことを認めた．この傾向は，上述の定温保持の 結果之一致している.

\section{謝 辞}

材料を提供していただいた住友軽金属工業侏また実験 遂行に際して協力していただいた渡辺做工学士に梁く感 謝します。

\section{参考 文 献}

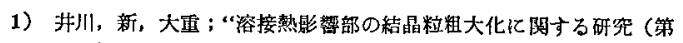
1 報) ”本誌 42巻 (1973) 8 号134 145

2) R. Kašpar, J. Pluhař ; "Recrystallization of Previously Recovered Aluminium", Metal Science, Vol. 9 (1975), 104 109

3）趡波，福井，杉山；“工業用純アルミニウムの容接熱影整部の再結 晶举動について”，本誌43巻 (1974) 3 号274 281

4) H.J. McQueen ; "The Production and Utility of Recovered Dislocation Structures" Metallurgical Transaction A, Vol. 8A (1977) No. 6, 807 824

5) P.L. Morris, B.J. Duggen; "Precipitation and recrystallization in an Al-1.8Mn alloy", Metal Science Vol. 12 (1978), No. $1,1 \sim 7$ 